\title{
Monensin for Lactating Dairy Cows Grazing Mixed-Alfalfa Pasture and Supplemented with Partial Mixed Ration
}

\author{
M. R. Gallardo, ${ }^{1}$ A. R. Castillo, ${ }^{2}$ F. Bargo, ${ }^{3,5}$ A. A. Abdala, ${ }^{1}$ M. G. Maciel, ${ }^{1}$ \\ H. Perez-Monti, ${ }^{4}$ H. C. Castro, ${ }^{1}$ and M. E. Castelli ${ }^{1}$ \\ ${ }^{1}$ Estación Experimental INTA Rafaela, Argentina 2300 \\ ${ }^{2}$ University of California, Cooperative Extension, Merced, 95340 \\ ${ }^{3}$ Facultad de Agronomía, Universidad de Buenos Aires, Argentina 1417 \\ ${ }^{4}$ Elanco Animal Health, Eli Lilly Interamerica Inc., Buenos Aires, Argentina 1425 \\ ${ }^{5}$ External Consultant Elanco Animal Health, Eli Lilly Interamerica Inc., Buenos Aires, Argentina 1425
}

\begin{abstract}
The effect of monensin on milk production was evaluated in 58 lactating Holstein cows (48 multiparous; 10 primiparous) grazing a mixed-alfalfa pasture and supplemented with a partial mixed ration in a completely randomized design with repeated measurements. Cows were paired by calving date, lactation number, previous lactation milk production, body weight, and body condition score and were assigned to one of 2 treatments: control or monensin. Cows on the monensin treatment received 2 monensin controlled-release capsules (335 $\mathrm{mg} / \mathrm{d}$ for $90 \mathrm{~d}$ ), one $30 \mathrm{~d}$ before the expecting calving date and the other $60 \mathrm{~d}$ after calving. Short-term ( 0 to $150 \mathrm{~d}$ in milk) and long-term (305-d adjusted lactation) effects of monensin were evaluated. Pasture (measured by difference between pre- and postgrazing pasture mass), supplements, and total dry matter intake did not differ between treatments and averaged 8.7, 14.1, and $22.9 \mathrm{~kg} / \mathrm{d}$, respectively. In the short-term, monensin increased milk production ( $27.7 \mathrm{vs} .26 .6 \mathrm{~kg} / \mathrm{d})$ and milk protein yield ( 0.890 vs. $0.860 \mathrm{~kg} / \mathrm{d})$; milk fat yield was not affected $(0.959 \mathrm{~kg} / \mathrm{d})$. Monensin decreased milk fat content (3.51 vs. $3.60 \%$ ) with no changes in milk protein content $(3.25 \%)$. In the long term, milk production and milk protein yield were also increased by monensin: 214 and $7 \mathrm{~kg}$, respectively. Monensin reduced the loss of body condition score and increased percentage of pregnancy at first service ( 44.8 vs. $20.7 \%$ ). Monensin improves production and reproduction performance of dairy cows grazing a mixed-alfalfa pasture and supplemented with a partial mixed ration.
\end{abstract}

(Key words: monensin, dairy cow, mixed-alfalfa pasture, partial mixed ration)

Received July 5, 2004.

Accepted October 15, 2004.

Corresponding author: M. R. Gallardo; e-mail: mgallardo@ rafaela.inta.gov.ar.
Abbreviation key: $\mathbf{C R C}=$ controlled-release capsule, PUN = plasma urea nitrogen.

\section{INTRODUCTION}

Milk production on pasture-based feeding systems is lower compared with milk production on TMR feeding systems because total DM and energy intake is lower (Bargo et al., 2002). The production performance of dairy cows expected on high quality pasture depends on many factors including pasture species (Bargo et al., 2003). Grazing high quality alfalfa resulted in greater risk of bloat, low rumen $\mathrm{pH}$, low effective NDF, and greater rumen ammonia nitrogen concentrations (Waghorn and Barry, 1987). Therefore, pasture-based feeding systems for high-producing dairy cows require the use of supplemental feeds such as concentrates and conserved forages (Bargo et al., 2003). Supplementation of pastures with a partial mixed ration in a feeding system called partial TMR is an alternative to improve milk production and composition of high-producing dairy cows in the United States and other countries such as Argentina (Bargo et al., 2002).

Monensin sodium is an ionophore approved for use in lactating dairy cows in several countries including Australia, Argentina, Brazil, New Zealand, South Africa, and recently the United States. A major benefit of feeding ionophores to lactating dairy cows is the shift in the acetate-to-propionate ratio toward more propionate and the associated decrease in methanogenesis (Russell and Houlihan, 2003). Based on the potential of ionophores to increase the supply of glucogenic precursors such as propionate, the administration of monensin to dairy cows may increase the hepatic synthesis of glucose and, therefore, improve the energy balance (Ipharraguerre and Clark, 2003). Benefits of feeding monensin to lactating dairy cows include increased milk production (McGuffey et al., 2001), antiketogenic effects, improved BCS (Sauer et al., 1989; Duffield et al., 1998), prevention of ruminal acidosis (McGuffey et al., 2001), and legume bloat control (Maas et al., 2002). 
Most of the studies regarding the feeding of monensin to lactating dairy cows were conducted under nongrazing conditions with dairy cows fed TMR (Ipharraguerre and Clark, 2003), which may not be representative of grazing cows (Maas et al., 2002). Few studies were conducted with dairy cows grazing (Wilson et al., 1993; Hayes et al., 1996; van der Merwe et al., 2001) or consuming fresh pasture (Ruiz et al., 2001), and those studies had a short length of 2 (Ruiz et al., 2001) to $6 \mathrm{wk}$ (van der Merwe et al., 2001). Most of those studies were conducted with low-producing dairy cows on pastureonly diets (Wilson et al., 1993; Hayes et al., 1996) and did not measure pasture DMI. None of the previous pasture studies included the use of pasture plus a partial mixed ration in a partial TMR feeding system. Information about the short- and long-term effects of monensin on production and reproduction performance is also needed (McGuffey et al., 2001). The objectives of our study were to evaluate short- and long-term effects of monensin controlled-released capsule (CRC; Rumensin, Elanco, Eli Lilly Interamerica Inc., Buenos Aires, Argentina) provided prepartum and in early lactation on milk production and composition, BCS, plasma metabolites, and reproduction variables of dairy cows grazing a mixed-alfalfa pasture and supplemented with partial mixed ration.

\section{MATERIALS AND METHODS}

\section{Cows and Treatments}

The experiment was conducted at the Experimental Station of the National Institute of Agriculture Technology (INTA) in Rafaela, province of Santa Fé, Argentina $\left(31^{\circ} 11^{\prime}\right.$ South) starting in January 2002. Fifty-eight Holstein cows [48 multiparous; 10 primiparous; BW, $605 \pm 64 \mathrm{~kg}$; dry period BCS, $3.46 \pm 0.11$; previous lactation milk production, $6984 \pm 942 \mathrm{~kg}$; parity, $3.6 \pm$ 1.8 (mean $\pm \mathrm{SE})$ ] were used in a completely randomized design with repeated measurements. Average calving date was March 10, 2002 and ranged from February 4 to April 24. Thirty days before the expected calving date, cows were paired according to calving date, parity, previous lactation milk production, BW, and BCS, and randomly assigned to one of 2 treatments: control or monensin. Cows on the monensin treatment received 2 monensin CRC: one $30 \mathrm{~d}$ before the expected calving date and the other $60 \mathrm{~d}$ after calving. The CRC delivers $335 \mathrm{mg} / \mathrm{d}$ of monensin for $90 \mathrm{~d}$. Previous studies with dairy cows (Lean et al., 1993; Plaizier et al., 2000; Vallimont et al., 2001) have reported that the effects of prepartum monesin feeding carried over postpartum. The effects of monensin CRC were evaluated in the short term (first 150 DIM) and long term (305-d adjusted lactation). From 150 DIM to the end of the lactation,
Table 1. Ingredient and chemical composition of TMR fed $30 \mathrm{~d}$ prepartum and during wk 1 postpartum of dairy cows grazing mixed-alfalfa pasture and supplemented with a partial mixed ration with or without monensin.

\begin{tabular}{lcc}
\hline & \multicolumn{2}{c}{ TMR } \\
\cline { 2 - 3 } Item & Prepartum & Postpartum \\
\hline Ingredient composition, \% & 42.0 \\
Corn silage & 35.0 & 32.5 \\
Alfalfa hay & 20.5 & 39.5 \\
Concentrate mix ${ }^{1}$ & 2.5 & 24.8 \\
Mineral and vitamin mix ${ }^{2}$ & $77: 23$ & 3.2 \\
F:C & & $72: 28$ \\
Chemical composition & 51.4 & 59.0 \\
DM, \% & 92.3 & 92.3 \\
OM, \% of DM & 13.3 & 16.8 \\
CP, \% of DM & 42.7 & 37.7 \\
NDF, \% of DM & 25.4 & 23.5 \\
ADF, \% of DM & 5.5 & 5.4 \\
Lignin, \% of DM & 3.6 & 3.9 \\
Fat, \% of DM & 32.7 & 34.0 \\
NFC, $\%$ of DM & 1.50 & 1.58 \\
NE ${ }_{\text {, }}^{6}$ Mcal/kg & & \\
\hline
\end{tabular}

${ }^{1}$ Concentrate mix $=$ prepartum $(50 \%$ corn grain, $30 \%$ wheat grain, and $20 \%$ wheat bran); postpartum [60\% corn grain, $13 \%$ wheat grain, $16 \%$ wheat bran, and $11 \%$ soybean meal $(44 \% \mathrm{CP})]$.

${ }^{2}$ Mineral and vitamin $\operatorname{mix}=31.5 \%$ calcium carbonate, $18.5 \%$ magnesium oxide, $38.4 \%$ dicalcium phosphate, $11.6 \%$ salt, $4.5 \mathrm{mg} / \mathrm{kg} \mathrm{Cu}$, $31 \mathrm{mg} / \mathrm{kg} \mathrm{Zn}, 33 \mathrm{mg} / \mathrm{kg}$ Fe, $0.6 \mathrm{mg} / \mathrm{kg} \mathrm{I}, 0.12 \mathrm{mg} / \mathrm{kg} \mathrm{Se}, 0.375 \mathrm{mg} / \mathrm{kg}$ Co, $4620 \mathrm{IU} / \mathrm{kg}$ vitamin A, $920 \mathrm{IU} / \mathrm{kg}$ vitamin $\mathrm{D}$, and $12 \mathrm{IU} / \mathrm{kg}$ vitamin E.

${ }^{3} \mathrm{~F}: \mathrm{C}=$ Forage to concentrate ratio.

${ }^{4} 72 \%$ sulfuric acid lignin (Van Soest et al., 1991).

${ }^{5} \mathrm{NFC}=[100-(\mathrm{ash}+\mathrm{CP}+\mathrm{NDF}+$ fat $)]$.

${ }^{6} \mathrm{Net}$ energy estimated from the model of The Ohio State University (Weiss et al., 1992).

all cows were managed together with the main herd of the Experimental Station of INTA Rafaela.

\section{Feeding and Grazing Management}

During the $30 \mathrm{~d}$ prepartum and wk 1 postpartum, all cows were held in a dry lot pen and received a TMR with forage-to-concentrate ratio of 77:23 and 72:28, respectively (Table 1 ). The amount of TMR was offered daily to ensure approximately $10 \%$ orts. Dry matter intake was measured by difference between offered and refused in all cows and averaged $13.6( \pm 1.3)$ and 16.8 $( \pm 2.0) \mathrm{kg} / \mathrm{d}$ for the $30 \mathrm{~d}$ prepartum and wk 1 postpartum TMR, respectively. Although that would have been an important period to measure individual DMI (Arieli et al., 2001; Vallimont et al., 2001), all cows were groupfed in one group; therefore, it was not possible to have statistically valid prepartum DMI measurements.

After wk 1 of lactation, cows were fed with concentrates and TMR and gradually began to have access to a mixed-alfalfa pasture. In the Rafaela area (province of Santa Fé, Argentina), it is possible to graze all year because weather conditions are not extreme (i.e., no 
snow cover during winter). Control and monensin cows were separately managed when grazed, in the feeding pens where they received the supplemented TMR, and in the milking parlor where received the concentrate. Control and monensin cows were fed separately a cornbased concentrate during the milking times (0400 and $1700 \mathrm{~h}$ ) and a TMR after the a.m. milking until $1100 \mathrm{~h}$. Control and monensin cows grazed separately a pasture paddock from $1100 \mathrm{~h}$ to the next day at $0400 \mathrm{~h}$, except for the time of p.m. milking. Pasture was managed on a single daily strip grazing system with electric fences. No irrigation or fertilization was applied to the mixedalfalfa pasture during the trial. Pasture botanical composition was $82 \%( \pm 9 \%)$ alfalfa (Medicago sativa L.), $6 \%$ $( \pm 1 \%$ ) bromegrass (Bromus spp.), $5 \%$ ( $\pm 2 \%$ ) white clover (Trifolium repens L.), and 7\% ( $\pm 2 \%)$ weeds.

\section{DMI Measurements and Feed Sample Analyses}

Dry matter intake was measured 3 times during the experiment in 5 groups per treatment (a total of 10 groups) of 5 to 6 cows each (a total of 58 cows). Each of the 3 DMI measurements was conducted for a 6-d period. The DMI measurements were conducted when cows averaged 60, 90, and 150 DIM. Because average calving date was March 10, DMI measurements corresponded in average to May 9, June 8, and July 8 ( $\pm 6 \mathrm{~d}$; Rafaela, Argentina, $31^{\circ} 11^{\prime}$ South). Because all of the ingredients in the diets were group-fed to cows, the group or paddock of cows was used as an experimental unit.

Pasture DMI was estimated in five $400-\mathrm{m}^{2}$ pasture paddocks per treatment by difference between pre- and postgrazing pasture mass according to the method described by Meijs et al. (1982). Pasture DMI measurement by difference between pre- and postgrazing pasture mass has been recently compared with other techniques and validated by Macoon et al. (2003). Within each pasture paddock, 6 pre- and 6 postgrazing $0.25-\mathrm{m}^{2}$ pasture mass samples were taken by cutting to ground level with manual scissors. For the entire trial, preand postgrazing pasture mass averaged $2105( \pm 234)$ and $553( \pm 109) \mathrm{kg} / \mathrm{ha}$ of DM, respectively. The amount of pasture offered on a daily basis or pasture allowance ranged from 14.7 to $16.8 \mathrm{~kg} / \mathrm{d}$ of DM per cow. The DMI of concentrate and TMR were daily measured by difference between the amount of concentrate or TMR offered minus the amount of concentrate or TMR refused during each 6 -d period in the 5 groups of cows per treatment.

For each of the 3 pasture DMI measurements, chemical composition of the pasture consumed by cows was estimated indirectly by difference as described by Meijs et al. (1982). Pre- and postgrazing pasture mass sam- ples were used to provide subsamples for chemical analysis. Each nutrient quantity removed during grazing was calculated and expressed as a percentage of DM using the following equation:

$$
\mathrm{X}=\left[\left(\mathrm{Y}-\mathrm{Y}^{\mathrm{f}}\right) /\left(\mathrm{M}-\mathrm{M}^{\mathrm{f}}\right)\right] \times 100
$$

where $\mathrm{X}=$ concentration of nutrient in pasture consumed, $\mathrm{Y}=$ pregrazing nutrient $(\mathrm{kg} / \mathrm{ha}), \mathrm{Y}^{\mathrm{f}}=$ postgrazing nutrient $(\mathrm{kg} / \mathrm{ha}), \mathrm{M}=$ pregrazing $\mathrm{DM}(\mathrm{kg} / \mathrm{ha})$, and $\mathrm{M}^{\mathrm{f}}$ = postgrazing $\mathrm{DM}(\mathrm{kg} / \mathrm{ha})$.

Concentrate and TMR samples were also taken for chemical composition analysis during the same $6 \mathrm{~d}$ that pre- and postgrazing pasture mass samples were taken.

Pasture, concentrate, and TMR samples were dried at $55^{\circ} \mathrm{C}$ for $48 \mathrm{~h}$ in a forced-air oven and ground through a 1-mm screen (Wiley Mill, Thomas Scientific, Philadelphia, PA) and then analyzed for DM, CP, ash, fat (AOAC, 1990), NDF, ADF, and lignin (Van Soest et al., 1991). Energy concentration $\left(\mathrm{NE}_{\mathrm{L}} / \mathrm{kg}\right.$ of $\left.\mathrm{DM}\right)$ of the diets was calculated according to The Ohio State University model (Weiss et al., 1992).

Chemical composition of the mixed-alfalfa pasture consumed (Meijs et al., 1982) when cows averaged 60, 90 , and 150 DIM is shown in Table 2 to show changes in pasture composition over each pasture DMI measurement. It should be noted, however, that pasture composition might well have changed more than is represented by Table 2 . On average, mixed-alfalfa pasture consumed by cows had high $\mathrm{CP}(>25 \%)$ and low DM $(<20 \%), \mathrm{NDF}(<35 \%)$, and NFC $(<25 \%)$. The corn-based concentrate had $16 \%$ of CP and $56 \%$ of NFC (Table 2). The TMR supplemented had low CP (11\%) to compensate for the high $\mathrm{CP}$ of the mixed-alfalfa pasture (Table 2).

\section{Milk Production and Composition, BCS, Blood Samples, and Reproductive Performance: Measurements and Sample Analyses}

Milk production was recorded daily by an AFIMILK computerized system (Afikim, Israel). Individual a.m. and p.m. milk samples were taken weekly on $2 \mathrm{~d}$ and composited during the first 150 DIM. These milk samples were analyzed for content of fat, total protein, and MUN by infrared spectrophotometry (Foss 605B MilkScan; Foss Electric, Hillerød, Denmark). After 150 DIM, individual a.m and p.m. milk samples were taken once per month and composited until the end of lactation to evaluate the long-term effects. These milk samples were analyzed for content of fat and total protein by infrared spectrophotometry (Foss 605B Milk-Scan; Foss Electric). 
Table 2. Chemical composition of the mixed-alfalfa pasture, concentrate, and TMR (mean $\pm \mathrm{SE}$ ) and ingredients and estimated chemical composition of the total diet at 60,90, and 150 DIM of dairy cows grazing a mixed-alfalfa pasture and supplemented with a partial mixed ration with or without monensin.

\begin{tabular}{|c|c|c|c|c|c|}
\hline \multirow[b]{2}{*}{ Item } & \multicolumn{3}{|c|}{ Mixed-alfalfa pasture ${ }^{1}$} & \multirow[b]{2}{*}{ Concentrate $^{2}$} & \multirow[b]{2}{*}{$\mathrm{TMR}^{3}$} \\
\hline & 60 DIM & 90 DIM & $150 \mathrm{DIM}$ & & \\
\hline $\mathrm{DM}, \%$ & $20.5 \pm 0.8$ & $17.8 \pm 0.6$ & $17.2 \pm 1.4$ & $89.9 \pm 1.2$ & $46.0 \pm 1.5$ \\
\hline $\mathrm{OM}, \%$ of $\mathrm{DM}$ & $89.8 \pm 9.9$ & $88.1 \pm 4.4$ & $88.9 \pm 8.8$ & $95.9 \pm 2.3$ & $92.4 \pm 9.7$ \\
\hline $\mathrm{CP}, \%$ of $\mathrm{DM}$ & $24.3 \pm 3.5$ & $32.8 \pm 1.4$ & $28.2 \pm 0.8$ & $16.2 \pm 0.6$ & $11.1 \pm 0.6$ \\
\hline $\mathrm{NDF}, \%$ of $\mathrm{DM}$ & $35.0 \pm 8.6$ & $28.8 \pm 1.5$ & $27.5 \pm 2.5$ & $18.5 \pm 1.1$ & $47.5 \pm 2.4$ \\
\hline $\mathrm{ADF}, \%$ of $\mathrm{DM}$ & $25.9 \pm 6.5$ & $19.6 \pm 4.6$ & $19.9 \pm 0.6$ & $6.5 \pm 1.3$ & $30.7 \pm 3.4$ \\
\hline Lignin, ${ }^{4} \%$ of DM & $5.3 \pm 1.7$ & $4.6 \pm 0.8$ & $5.6 \pm 0.6$ & $4.4 \pm 0.8$ & $7.3 \pm 1.1$ \\
\hline Fat, $\%$ of DM & $5.1 \pm 1.1$ & $5.3 \pm 1.2$ & $5.5 \pm 0.9$ & $5.5 \pm 1.0$ & $6.0 \pm 1.6$ \\
\hline $\mathrm{NFC}, 5 \%$ of DM & $25.5 \pm 7.5$ & $21.3 \pm 2.4$ & $27.7 \pm 3.1$ & $55.7 \pm 2.0$ & $27.9 \pm 2.8$ \\
\hline \multirow{2}{*}{\multicolumn{6}{|c|}{ Ingredient, \% }} \\
\hline & & & & & \\
\hline TMR & 32.6 & 44.0 & 43.3 & & \\
\hline Concentrate & 23.5 & 18.0 & 19.0 & & \\
\hline Mineral and vitamin & 2.0 & 2.0 & 2.1 & & \\
\hline Total & 100.0 & 100.0 & 100.0 & & \\
\hline \multicolumn{6}{|l|}{ Chemical composition } \\
\hline $\mathrm{DM}, \%$ & 47.2 & 45.2 & 44.1 & & \\
\hline $\mathrm{OM}, \%$ of $\mathrm{DM}$ & 92.2 & 92.0 & 91.4 & & \\
\hline $\mathrm{CP}, \%$ of DM & 17.9 & 19.8 & 18.1 & & \\
\hline $\mathrm{NDF}, \%$ of $\mathrm{DM}$ & 36.0 & 35.6 & 34.0 & & \\
\hline $\mathrm{ADF}, \%$ of $\mathrm{DM}$ & 23.8 & 21.6 & 21.0 & & \\
\hline Lignin, ${ }^{4} \%$ of DM & 5.0 & 4.4 & 6.4 & & \\
\hline Fat, $\%$ of DM & 5.8 & 5.7 & 4.7 & & \\
\hline $\mathrm{NFC},{ }^{5} \%$ of DM & 32.5 & 30.9 & 34.6 & & \\
\hline $\mathrm{NE}_{\mathrm{L}},{ }^{7} \mathrm{Mcal} / \mathrm{kg}$ & 1.65 & 1.66 & 1.62 & & \\
\hline
\end{tabular}

\footnotetext{
${ }^{1}$ Represents the pasture consumed estimated by the method described by Meijs et al. (1982).

${ }^{2}$ Concentrate $=60 \%$ corn grain, $16 \%$ wheat bran, $13 \%$ wheat grain, and $11 \%$ soybean meal $(44 \% \mathrm{CP})$. ${ }^{3} \mathrm{TMR}=73 \%$ corn silage, $16 \%$ alfalfa hay, and $11 \%$ whole cottonseed.

${ }^{4} 72 \%$ sulfuric acid lignin (Van Soest et al., 1991).

${ }^{5} \mathrm{NFC}=100-($ ash $+\mathrm{CP}+\mathrm{NDF}+$ fat $)$.

${ }^{6}$ Total diet ingredients and chemical composition calculated from nutrient composition of ingredients and mixed-alfalfa pasture, TMR, and concentrate DMI (Table 3).

${ }^{7}$ Net energy estimated from the model of The Ohio State University (Weiss et al., 1992).
}

Body condition of the cows was scored by 3 experienced independent observers using the 5-point BCS scale $(1=$ thin to 5 = fat; Wildman et al., 1982) on d 30 before the expected calving date, at calving, and every 3 wk during the following 150 DIM. Blood samples were taken immediately after the a.m. milking from the coccygeal vessels into one $20-\mathrm{mL}$ evacuated tube containing anticoagulant (heparin and sodium fluoride) and one $20-\mathrm{mL}$ evacuated tube without anticoagulant on $\mathrm{d} 21$ before the expected calving date, at parturition, and on $\mathrm{d} 10$ and 21 postpartum. Blood was immediately placed on ice and transported to the laboratory. Samples were centrifuged at $3000 \times g$ for $15 \mathrm{~min}$ at $4^{\circ} \mathrm{C}$. Plasma was analyzed for glucose and urea nitrogen (Wiener Laboratory, Rosario, Argentina) and for NEFA (Randox Laboratories Ltd., UK). Reproductive performance was evaluated by the percentage of pregnancy at first insemination, at $6 \mathrm{wk}$, and at $12 \mathrm{wk}$ from the start mating date.

\section{Statistical Analysis}

Data were analyzed as a completely randomized design with repeated measurements using the PROC MIXED procedure of SAS (1999). For DMI data, the groups of cows were used as experimental unit. For milk production and composition, BCS, plasma metabolites, and reproduction performance data, the individual cows were used as experimental units. For the milk production data, the previous lactation milk production of multiparous cows and the BW of primiparous cows were used as covariates. Differences were declared significant at $P<0.05$.

During the study, 4 multiparous cows were eliminated because of mastitis (Staphylococcus aureus) after the reproductive performance data collection was completed. Thus, 58 cows were used for the statistical analysis of plasma metabolites and reproductive performance data, and 54 cows were used for the statistical 
Table 3. Effect of monensin on $\mathrm{DMI}^{1}$ at 60,90 , and $150 \mathrm{DIM}$ of dairy cows grazing a mixed-alfalfa pasture and supplemented with a partial mixed ration.

\begin{tabular}{|c|c|c|c|c|}
\hline \multirow[b]{2}{*}{ Item } & \multicolumn{2}{|c|}{ Treatment } & \multirow[b]{2}{*}{ SEM } & \multirow[b]{2}{*}{$P$} \\
\hline & Control & Monensin & & \\
\hline \multicolumn{5}{|l|}{ DMI, kg/d (60 DIM) } \\
\hline Mixed-alfalfa pasture & 9.9 & 9.8 & 1.6 & 0.944 \\
\hline $\mathrm{TMR}^{2}$ & 7.7 & 7.6 & 1.2 & 0.842 \\
\hline Concentrate $^{3}$ & 6.0 & 5.9 & 0.2 & 0.930 \\
\hline Total & 23.6 & 23.3 & 2.3 & 0.886 \\
\hline \multicolumn{5}{|l|}{ DMI, kg/d (90 DIM) } \\
\hline Mixed-alfalfa pasture & 8.6 & 8.7 & 0.9 & 0.827 \\
\hline TMR & 10.4 & 10.3 & 1.1 & 0.834 \\
\hline Concentrate & 4.6 & 4.5 & 0.5 & 0.855 \\
\hline Total & 23.6 & 23.5 & 1.6 & 0.972 \\
\hline \multicolumn{5}{|l|}{ DMI, kg/d (150 DIM) } \\
\hline Mixed-alfalfa pasture & 8.2 & 7.3 & 1.8 & 0.356 \\
\hline TMR & 9.5 & 9.3 & 0.5 & 0.575 \\
\hline Concentrate & 4.6 & 4.6 & 0.5 & 0.976 \\
\hline Total & 22.3 & 21.2 & 1.7 & 0.271 \\
\hline
\end{tabular}

${ }^{1}$ Estimated by difference between offered and refused in 5 groups per treatment each group with 5 to 6 cows.

${ }^{2} \mathrm{TMR}=73 \%$ corn silage, $16 \%$ alfalfa hay, and $11 \%$ whole cottonseed.

${ }^{3}$ Concentrate $=60 \%$ corn grain, $16 \%$ wheat bran, $13 \%$ wheat grain, and $11 \%$ soybean meal $(44 \% \mathrm{CP})$.

analysis of milk production and composition and BCS. No interactions $(P>0.05)$ between treatment and week of lactation were observed; therefore, only treatment effects are presented and discussed.

\section{RESULTS AND DISCUSSION}

DMI

For the entire trial, total DMI did not differ between treatments and averaged $22.9 \mathrm{~kg} / \mathrm{d}(P \geq 0.27$; Table 3$)$. Values of total DMI found in our study were high and consistent with the high milk production from calving to wk 20 of lactation ( $>27 \mathrm{~kg} / \mathrm{d}$; NRC, 2001). Mixedalfalfa pasture, TMR, and concentrate DMI did not differ between treatments and averaged 8.7, 9.1, and 5.0 $\mathrm{kg} / \mathrm{d}$, respectively $(P \geq 0.36$; Table 3$)$. Lack of effect of monensin on DMI is in agreement with a recent review by Ipharraguerre and Clark (2003). In 8 of 12 studies with lactating dairy cows, no significant effects of monensin on DMI were observed. None of the studies reviewed in which cows grazed pasture reported DMI (Ipharraguerre and Clark, 2003). Ruiz et al. (2001) reported no effects of monensin on fresh forage and concentrate DMI fed to dairy cows in confinement. Phipps et al. (2000) found a small nonsignificant reduction in DMI from 19.4 to $18.9 \mathrm{~kg} / \mathrm{d}$ in dairy cows fed a TMR as the dose of monensin increased from 0 to $450 \mathrm{mg} / \mathrm{d}$.
Table 4. Short-term effect ( 0 to 150 DIM) of monensin on milk production and composition of dairy cows grazing a mixed-alfalfa pasture and supplemented with a partial mixed ration.

\begin{tabular}{|c|c|c|c|c|}
\hline \multirow[b]{2}{*}{ Item } & \multicolumn{2}{|c|}{ Treatment } & \multirow[b]{2}{*}{ SEM } & \multirow[b]{2}{*}{$P$} \\
\hline & Control & Monensin & & \\
\hline Milk, kg/d & 26.6 & 27.7 & 0.17 & 0.001 \\
\hline $3.5 \%$ FCM, kg/d & 27.1 & 27.8 & 0.48 & 0.341 \\
\hline \multicolumn{5}{|l|}{ Fat } \\
\hline$\%$ & 3.60 & 3.51 & 0.03 & 0.038 \\
\hline $\mathrm{kg} / \mathrm{d}$ & 0.952 & 0.965 & 0.009 & 0.305 \\
\hline \multicolumn{5}{|l|}{ Total protein } \\
\hline$\%$ & 3.25 & 3.24 & 0.01 & 0.672 \\
\hline $\mathrm{kg} / \mathrm{d}$ & 0.860 & 0.890 & 0.005 & 0.001 \\
\hline MUN, mg/dL & 9.7 & 10.3 & 0.23 & 0.071 \\
\hline
\end{tabular}

\section{Milk Production and Composition, BCS, Plasma Metabolites, and Reproductive Variables}

Short-term effects of monensin on milk production and composition are shown in Table 4. Monensin increased milk production $4 \%$ (27.7 vs. $26.6 \mathrm{~kg} / \mathrm{d})$ during the first 150 DIM $(P=0.001$; Table 4 ; Figure 1$)$; however, it did not affect $3.5 \% \mathrm{FCM}(27.5 \mathrm{~kg} / \mathrm{d} ; P=0.341$; Table 4). Milk production levels are similar to those reported for high-producing dairy cows consuming a similar diet to the one used in our study that included $<50 \%$ pasture, TMR, and concentrate (Bargo et al., 2002). Response in milk production to monensin obtained in our experiment is in agreement with recent reviews (McGuffey et al., 2001; Ipharraguerre and Clark, 2003). Cows receiving monensin had a milk response that averaged $1.3 \mathrm{~kg} / \mathrm{d}$ or $5 \%$ in 11 monensin premix experiments (McGuffey et al., 2001), $1.1 \mathrm{~kg} / \mathrm{d}$ or $7 \%$ in 4 monensin CRC experiments (McGuffey et al., 2001), and $1.5 \mathrm{~kg} / \mathrm{d}$ or $7 \%$ in 14 experiments (Ipharraguerre and Clark, 2003) compared with the $1.1 \mathrm{~kg} / \mathrm{d}$ or $4 \%$ response of our study. Ipharraguerre and Clark

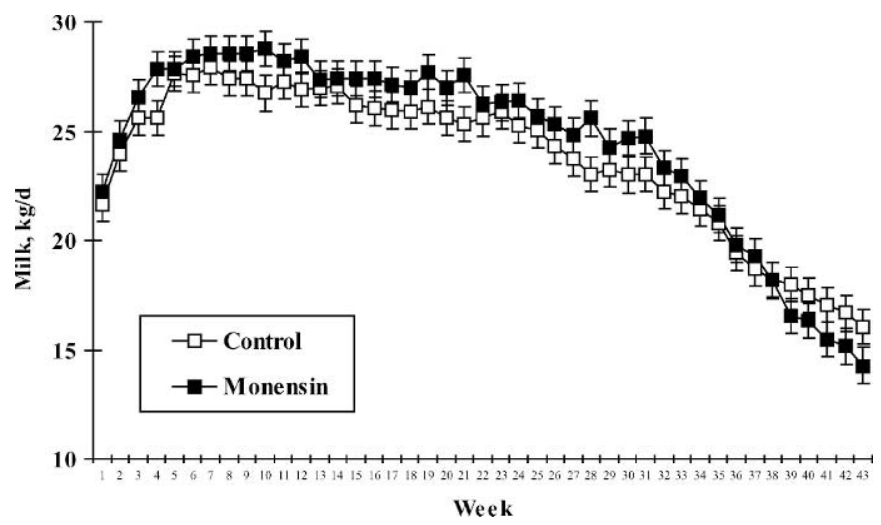

Figure 1. Average weekly milk production of dairy cows grazing a mixed-alfalfa pasture and supplemented with a partial mixed ration with or without monensin. Overall $\mathrm{SEM}=0.8 \mathrm{~kg} / \mathrm{d}$. 
(2003) reported that in 5 of 7 studies conducted with cows consuming pasture, milk response to monensin averaged $1.1 \mathrm{~kg} / \mathrm{d}$ with a range of 0.4 (Hayes et al., 1996) to $1.85 \mathrm{~kg} / \mathrm{d}$ (Ruiz et al., 2001). However, in most of these studies, cows were fed only pasture diets, and none of them included pasture supplementation with a partial mixed ration.

Monensin likely increases milk production because of an increased supply of glucogenic precursors caused by changes in rumen fermentation (Phipps et al., 2000). Other grazing studies (van der Merwe et al., 2001; Maas et al., 2002), however, did not report an increase in milk production of dairy cows receiving monensin. In the study of Maas et al. (2002), the level of milk production was lower $(<18 \mathrm{~kg} / \mathrm{d})$, monensin $\mathrm{CRC}$ was supplied after calving (at 47 DIM), and cows consumed only pasture, which is in contrast to our study. Milk fat yield did not differ $(P=0.305)$ between treatments and averaged $0.960 \mathrm{~kg} / \mathrm{d}$ because the reduction in milk fat content was compensated by the increase in milk production (Table 4).

Milk fat content was reduced $2.5 \%$ (3.51 vs. $3.60 \% ; P=$ 0.038 ) by monensin, but no differences were observed in content of total protein $(3.25 \% ; P=0.672$; Table 4$)$. Milk fat and protein content results were in agreement with the reviews of McGuffey et al. (2001) and Ipharraguerre and Clark (2003) that described that monensin decreased milk fat content with no effects on milk protein content. In over 30 studies, the administration of monensin to dairy cows reduced, numerically in 20 studies and significantly in 10 studies, the milk fat content (Ipharraguerre and Clark, 2003). In many of the studies where monensin reduced milk fat content, an increase in milk production was also observed; therefore, a dilution effect could be part of this result (Ipharraguerre and Clark, 2003). This is in agreement with the similar milk fat yield between treatments found in our study (Table 4). Ruiz et al. (2001), however, did not find differences in milk fat content of dairy cows fed fresh forage with or without monensin. No differences in milk fat and protein content were reported by van der Merwe et al. (2001) for dairy cows grazing kikuyu and clover pastures. Ipharraguerre and Clark (2003) reported that only in 3 of 24 studies, milk protein content was reduced by the administration of monensin. Milk total protein yield increased with monensin $(0.890$ vs. $0.860 \mathrm{~kg} / \mathrm{d}$; $P=0.001$; Table 4 ). No differences in milk protein yield were reported for grazing dairy cows (Hayes et al., 1996). Monensin increased MUN concentration (10.3 vs. $9.7 \mathrm{mg} / \mathrm{dL} ; P=0.071$; Table 4 ). However, other studies did not find differences in MUN content with dairy cows fed fresh temperate pastures (Ruiz et al., 2001). van der Merwe et al. (2001) reported lower MUN concentration for grazing dairy cows receiving monensin.
Table 5. Long-term effect (305-d adjusted lactation) of monensin on milk production and composition of dairy cows grazing a mixed-alfalfa pasture and supplemented with a partial mixed ration.

\begin{tabular}{|c|c|c|c|c|}
\hline \multirow[b]{2}{*}{ Item } & \multicolumn{2}{|c|}{ Treatment } & \multirow[b]{2}{*}{ SEM } & \multirow[b]{2}{*}{$P$} \\
\hline & Control & Monensin & & \\
\hline Milk, kg/d & 23.8 & 24.5 & 0.12 & 0.001 \\
\hline $\begin{array}{l}3.5 \% \text { FCM, } \mathrm{kg} / \mathrm{d} \\
\text { Fat }\end{array}$ & 24.0 & 24.4 & 0.31 & 0.532 \\
\hline$\%$ & 3.56 & 3.47 & 0.03 & 0.018 \\
\hline $\mathrm{kg} / \mathrm{d}$ & 0.899 & 0.907 & 0.008 & 0.479 \\
\hline Total protein & & & & \\
\hline$\%$ & 3.27 & 3.26 & 0.01 & 0.356 \\
\hline $\mathrm{kg} / \mathrm{d}$ & 0.827 & 0.850 & 0.005 & 0.001 \\
\hline
\end{tabular}

Long-term effects of monensin on milk production and composition are presented in Table 5. Most of the studies published have evaluated monensin effects only in the short term (McGuffey et al., 2001). Total lactation milk production adjusted to $305 \mathrm{~d}$ was $3 \%$ greater $(P=$ 0.001 ) when cows received monensin with an averaged response of $0.7 \mathrm{~kg} / \mathrm{d}$ or $214 \mathrm{~kg}$ per lactation compared with the control. Monensin did not affect 3.5\% FCM production that averaged $24.2 \mathrm{~kg} / \mathrm{d}(P=0.532$; Table 5). Monensin reduced milk fat content in the complete lactation (3.47 vs. $3.56 \% ; P=0.018)$, without affecting milk total protein content $(3.27 \% ; P=0.356$; Table 5$)$. No differences were observed in milk fat yield $(0.90 \mathrm{~kg} /$ d; $P=0.479$ ); however, monensin increased milk total protein yield in the entire lactation $2.8 \%$ ( 0.850 vs. 0.827 $\mathrm{kg} / \mathrm{d} ; P=0.001 ; 259$ vs. $252 \mathrm{~kg}$ per lactation).

Body condition score, plasma metabolites, and reproductive variables are presented in Table 6 . The use of monensin in the diet of grazing dairy cows supplemented with partial mixed ration resulted in greater mean BCS (2.92 vs. $2.82 ; P=0.009$; Table 6$)$. Thirty days before the expected calving date, BCS was similar between treatments and averaged 3.46 (Figure 2). Monensin cows had greater BCS at calving (3.21 vs. 2.96; $P=0.009$ ), at $21 \mathrm{DIM}(2.89$ vs. $2.73 ; P=0.129)$, and at 105 DIM (2.82 vs. 2.66; $P=0.112$; Figure 2). Change of BCS was also affected by monensin (Table 6). Cows on the control treatment lost more BCS between $30 \mathrm{~d}$ before parturition and calving date $(-0.49$ vs. $-0.26 ; P=$ 0.010 ) and between $30 \mathrm{~d}$ before parturition and $21 \mathrm{DIM}$ (-0.71 vs. $-0.60 ; P=0.311)$, respectively. Between 21 and 147 DIM, both treatment maintained BCS with an average change of $-0.02(P=0.434)$. Similar results on BCS after calving were reported by Duffield et al. (1998) and Ramanzin et al. (1997). These results could be related to a better energy balance in favor of the monensin treatment, probably because of a lower mobilization of body reserves.

Monensin reduced the mean concentration of NEFA (470 vs. $540 \mu \mathrm{eq} / \mathrm{L} ; P=0.054)$, which supports the 
Table 6. Effect of monensin on BCS, plasma metabolites, and reproductive variables of dairy cows grazing a mixed-alfalfa pasture and supplemented with a partial mixed ration.

\begin{tabular}{lcccc}
\hline & \multicolumn{2}{c}{ Treatment } & & \\
\cline { 2 - 3 } Item & Control & Monensin & SEM & $P$ \\
\hline BCS, 1 to 5 & & & & \\
Mean & 2.82 & 2.92 & 0.02 & 0.009 \\
Change (-30 to calving) & -0.49 & -0.26 & 0.05 & 0.010 \\
Change (-30 to 21 DIM) & -0.71 & -0.60 & 0.08 & 0.311 \\
Change (21 to 147 DIM) & 0.03 & -0.06 & & 0.434 \\
Plasma metabolites & & & & \\
NEFA, $\mu$ eq/L & 540 & 470 & 15 & 0.054 \\
Mean & 420 & 350 & 50 & 0.321 \\
-21 d calving & 720 & 660 & 50 & 0.412 \\
Calving & 590 & 470 & 25 & 0.899 \\
10 DIM & 420 & 410 & 0.9 & 0.222 \\
21 DIM & 59.3 & 61.1 & & 0.030 \\
Glucose, mg/dL & 9.1 & 10.4 & 8.1 & 0.049 \\
PUN, ${ }^{1}$ mg/dL & & 44.8 & 9.5 & 0.291 \\
Reproductive variables & 20.7 & 55.2 & & 0.101 \\
\% Pregnancy first AI & 41.4 & 75.9 &
\end{tabular}

${ }^{1} \mathrm{PUN}=$ Plasma urea nitrogen.

greater mean BCS found on the monensin treatment (Table 6). Monensin also decreased concentration of NEFA at 10 DIM (470 vs. $590 \mu \mathrm{eq} / \mathrm{L} ; P=0.078$; Table 6). Other researchers have reported similar results (Ramanzin et al., 1997; Sauer et al., 1989; Duffield et al., 2003). On the other hand, previous grazing studies with low-producing dairy cows (Hayes et al., 1996; Maas et al., 2002) reported no differences in NEFA concentrations. Lack of agreement between previous grazing studies and our study might have been related to the earlier stage of lactation, greater milk production (Table 4), and type of diet (pasture supplemented with concentrate and TMR).

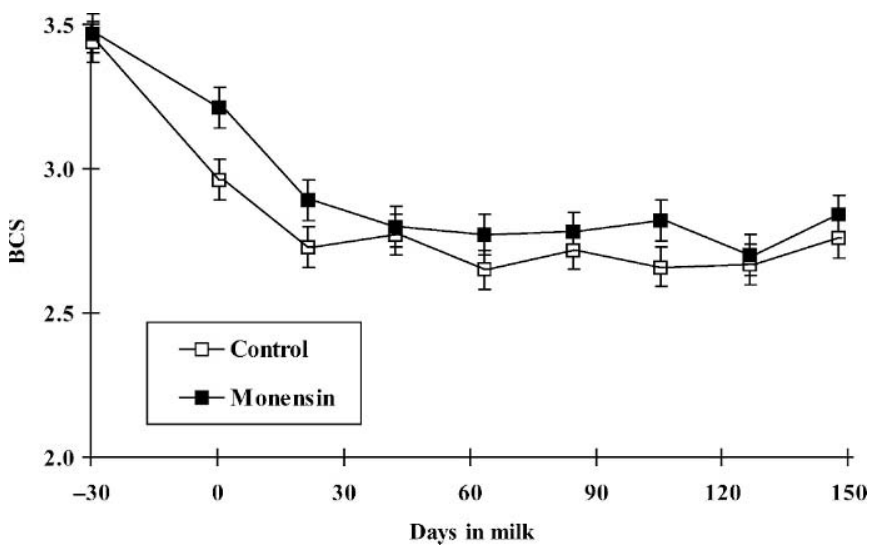

Figure 2. Body condition score of dairy cows grazing a mixedalfalfa pasture and supplemented with a partial mixed ration with or without monensin. Overall SEM $=0.07$.
Plasma glucose concentration did not differ between treatments and averaged $60.2 \mathrm{mg} / \mathrm{dL}(P=0.222$; Table 6). This agrees with the results of Hayes et al. (1996), who reported no differences in plasma glucose concentration of grazing dairy cows. Vallimont et al. (2001) reported similar plasma glucose concentration in dairy cows fed TMR and receiving monensin prepartum. In a field study involving 251 Holstein cows (Duffield et al., 2003), plasma glucose concentration was not affected by monensin CRC administered 3 wk precalving. In other studies (Duffield et al., 1998; Green et al., 1999; Phipps et al., 2000), however, greater plasma glucose concentrations were observed when monensin was added to the diet, including a grazing study (Maas et al., 2002). Increased plasma glucose concentration is probably related to the action of this ionophore on propionic acid production in the rumen and gluconeogenesis in the liver (Ipharraguerre and Clark, 2003). In over 13 studies where monensin was administered to lactating dairy cows, plasma glucose was significantly increased in only 4 studies and in all of them in a small proportion (5.9\%; Ipharraguerre and Clark, 2003). The lack of response on plasma glucose concentration to monensin does not deny the glucogenic effect of this ionophore, which was demonstrated by Arieli et al. (2001) using a tracer dose of $\mathrm{U}^{1}{ }^{13} \mathrm{C}$-labeled glucose. That study found that monensin increased the distribution space and pool size of glucose without affecting its mean plasma concentration (Arieli et al., 2001).

Plasma urea nitrogen (PUN) was greater with the inclusion of monensin ( $P=0.030$; Table 6$)$, in agreement with the greater MUN previously reported (Table 4). 
This agrees with previous studies that reported greater PUN in dairy cows receiving monensin (Green et al., 1999; Duffield et al., 2003), including a grazing study (Hayes et al., 1996). The increase in PUN can be related to the monensin capacity of decreasing ruminal degradation of proteins and peptides enhancing the absorption of amino acids and nitrogen at the small intestine (McGuffey et al., 2001; Ruiz et al., 2001). Others reported no differences in PUN when pasture- (Maas et al., 2002) or TMR-fed (Vallimont et al., 2001) cows received monensin.

Percentage of pregnancy was improved at first AI ( 44.8 vs. $20.7 \% ; P=0.049)$ and at wk 12 (75.9 vs. $55.2 \%$; $P=0.101$; Table 6 ). The greater mean BCS and lower mean NEFA concentration (Table 6) on the monensin treatment, resulting in an improvement in energy balance, could have influenced reproductive performance. It is well documented that negative energy balance during early lactation is associated with reduced fertility (Butler and Smith, 1989). In our study, a lesser negative energy balance in early lactation might have occurred even with a similar 3.5\% FCM production (Table 4), which could indicate similar total milk energy. Our results suggest that monensin could play a significant role in improving the fertility of supplemented grazing dairy cows. Lean et al. (1993) proposed that monensin might improve reproductive performance if its administration is early enough to remove the negative effects of reduced DMI in early lactation. Other grazing studies (Hayes et al., 1996), however, reported no improvement of reproductive performance (measured by first AI, second $\mathrm{AI}$, and cumulative pregnancy rates) when using monensin. More grazing studies with larger number of animals should be done to confirm our observations.

\section{CONCLUSIONS}

This is the first study that evaluated the effect of using monensin CRC prepartum and postpartum in lactating dairy cows grazing a mixed-alfalfa pasture and supplemented with a partial mixed ration. Results from this study suggest that the effects of prepartum feeding of monensin CRC does carry over in supplemented dairy cows on pasture. Feeding monensin did not affect DMI but increased milk and protein production without affecting 3.5\% FCM production. Monensin likely increased milk production because of an improved energy balance. Monensin reduced the content of milk fat but did not affect the content of milk protein. This suggests a dilution effect because yield of fat was not affected. Feeding monensin also reduced the loss of BCS, decreased the concentration of NEFA, and improved percentage of pregnancy, which supports the hypothesis of an improved energy balance in lactating dairy cows on pasture and supplement.

\section{ACKNOWLEDGMENTS}

The authors thank M. C. Gaggiotti, S. Aronna, A. Cuatrin, and S. P. Allassia for assistance in sampling and laboratory analyses during this experiment.

\section{REFERENCES}

Arieli, A., J. E. Vallimont, Y. Aharoni, and G. A. Varga. 2001. Monensin and growth hormone effects on glucose metabolism in the prepartum cow. J. Dairy Sci. 84:2770-2776.

Association of Official Analytical Chemists. 1990. Official Methods of Analysis. 15th ed. AOAC, Arlington, VA.

Bargo, F., L. D. Muller, J. E. Delahoy, and T. W. Cassidy. 2002. Performance of high producing dairy cows with 3 different feeding systems combining pasture and total mixed rations. J. Dairy Sci. 85:2948-2963.

Bargo, F., L. D. Muller, E. S. Kolver, and J. E. Delahoy. 2003. Invited review: Production and digestion of supplemented dairy cows on pasture. J. Dairy Sci. 86:1-42.

Butler, W. R., and R. D. Smith. 1989. Interrelationships between energy balance and postpartum reproductive function in dairy cattle. J. Dairy Sci. 72:767-783.

Duffield, T. F., S. LeBlanc, R. Bagg, K. Leslie, J. Ten Hag, and P. Dick. 2003. Effect of a monensin controlled release capsule on metabolic parameters in transition dairy cows. J. Dairy Sci. 86:1171-1176.

Duffield, T. F., D. Sandals, K. E. Leslie, K. Lissemore, B. W. McBride, J. H. Lumsden, P. Dick, and R. Bagg. 1998. Effect of prepartum administration of monensin in a controlled-release capsule on postpartum energy indicators in lactating dairy cows. J. Dairy Sci. 81:2354-2361.

Green, B. L., B. W. McBride, D. Sandals, K. E. Leslie, R. Bagg, and P. Dick. 1999. The impact of a monensin controlled-release capsule on sub-clinical ketosis in the transition dairy cow. J. Dairy Sci. 82:333-342.

Hayes, D. P., D. U. Pfeiffer, and N. B. Williamson. 1996. Effect of intraruminal capsules on reproductive performance and milk production of dairy cows fed pasture. J. Dairy Sci. 79:1000-1008.

Ipharraguerre, I. R., and J. H. Clark. 2003. Usefulness of ionophores for lactating dairy cows: A review. Anim. Feed Sci. Technol. 106:39-57.

Lean, I. J., N. Abe, A. Rabiee, and M. Curtis. 1993. Sodium monensin: Effects on production, metabolism and reproduction in dairy cattle. Page 33 in Gold Coast Proc. Aust. Assoc. Cattle Vet., Indooroopily, Queensland, Australia.

Maas, J. A., S. N. McCutcheon, G. F. Wilson, G. A. Lynch, M. E. Hunt, and L. A. Crompton. 2002. Effect of monensin sodium on lactational performance of autumn- and spring-calving cows. J. Dairy Res. 69:317-323.

Macoon, B., L. E. Sollenberger, J. E. Moore, C. R. Staples, J. H. Fike, and K. M. Portier. 2003. Comparison of three techniques for estimating the forage intake of lactating dairy cows on pasture. J. Anim. Sci. 81:2357-2366.

McGuffey, R. K., L. F. Richardson, and J. I. D. Wilkinson. 2001. Ionophores for dairy cattle: Current status and future outlook. J. Dairy Sci. 84(E. Suppl.):E194-E203.

Meijs, J. A. C., R. J. K. Walters, and A. Keen. 1982. Sward methods. Page 11 in Herbage Intake Handbook. J. D. Leaver, ed. Hurley, British Grassland Society, UK.

National Research Council. 2001. Pages 3-12 in Nutrient Requirements of Dairy Cattle. 7th rev. ed. Natl. Acad. Sci., Washington, DC.

Phipps, R. H., J. I. Wilkinson, L. J. Jonker, M. Tarrant, A. K. Jones, and A. Hodge. 2000. Effect of monensin on milk production of Holstein-Friesian dairy cows. J. Dairy Sci. 83:2789-2794. 
Plaizier, J. C., A. Martin, T. Duffield, R. Bagg, P. Dick, and B. W. McBride. 2000. Effect of prepartum administration of monensin in a controlled-release capsule on nitrogen utilization in transition dairy cows. J. Dairy Sci. 83:2918-2925.

Ramanzin, M., L. Bailoni, S. Schiavon, and G. Bittante. 1997. Effect of monensin on milk production and efficiency of dairy cows fed two diets differing in forage to concentrate ratios. J. Dairy Sci. 80:1136-1142.

Ruiz, R., G. L. Albrecht, L. O. Tedeschi, G. Jarvis, J. B. Rusell, and D. G. Fox. 2001. Effect of monensin on the performance and nitrogen utilization of lactating dairy cows consuming fresh forage. J. Dairy Sci. 84:1717-1727.

Russell, J. B., and A. J. Houlihan. 2003. Ionophore resistance of ruminal bacteria and its potential impact on human health. FEMS Microb. Rev. 27:65-74.

SAS Institute. 1999. Users Guide: Statistics, Version 6, 4th edition. SAS Inst., Inc., Cary, NC.

Sauer, F. D., J. K. G. Kramer, and W. J. Cantwell. 1989. Antiketogenic effects of monensin in early lactation. J. Dairy Sci. 72:436-442.

Vallimont, J. E., G. A. Varga, A. Arieli, T. W. Cassidy, and K. A. Cummins. 2001. Effects of prepartum somatotropin and monen- sin on metabolism and production of periparturient Holstein dairy cows. J. Dairy Sci. 84:2607-2621.

van der Merwe, B. J., T. J. Dugmore, and K. P. Walsh. 2001. The effect of monensin on milk production, milk urea nitrogen and body condition score of grazing dairy cows. S. Afr. J. Anim. Sci. 31:49-55.

Van Soest, P. J., J. B. Robertson, and B. A. Lewis. 1991. Methods for dietary fiber, neutral detergent fiber, and non starch polysaccharides in relation to animal nutrition. J. Dairy Sci. 74:3583.

Waghorn, G. C., and T. N. Barry. 1987. Pasture as a nutrient source. Page 21 in Livestock Feeding on Pasture. A. M. Nicol, ed., N. Z. Soc. Anim. Prod., Hamilton, New Zealand.

Weiss, W. P., H. R. Conrad, and N. R. St. Pierre. 1992. A theoreticallybased model for predicting total digestible nutrient values of forages and concentrates. Anim. Feed Sci. Technol. 39:95-110.

Wildman, E. E., G. M. Jones, P. E. Wagner, R. L. Boman, H. F. Troutt, and T. N. Lesch. 1982. A dairy cow body condition scoring system and it's relationship to selected production characteristics. J. Dairy Sci. 65:495-501.

Wilson, G. F., G. A. Lynch, and C. van der Wel. 1993. Effect of Rumensin anti-bloat capsules on plasma magnesium concentration and aspects of health and performance of pastured dairy cows. Proc. N. Z. Soc. Anim. Prod. 53:247-250. 